\title{
Instructional Design and Material Development Progress to eLearning Environments: A Sample of Obstetrical Nursing Education
}

\author{
Merve Kadioglu \\ Laboratory Corporation of America, USA \\ ORCID: 0000-0003-2833-7716 \\ Zeynep Tacgin \\ Marmara University Distance Education Center \& Social Science Vocational School, Turkey \\ ORCID: 0000-0001-7827-8238 \\ Nevin Sahin \\ Istanbul University Florence Nightingale Faculty of Nursing, Turkey \\ ORCID: 0000-0002-6845-2690
}

Received: 25 Jan 2020

Accepted: 5 Feb 2020

\begin{abstract}
The purpose of this study is to demonstrate the most delicate parts of eLearning material development process and tools from the Instructional Design (ID) perspective. In this context, the birth lesson eLearning material modules have been progressed in accordance with the design - based research approach. The selected two modules have been completed by the project team - 3 instructional designer, 1 subject expert, 1 education technologist and 2 subject matter consultants- in 8 months. The ID process has been started with the education need analysis in order to determine the learners' needs, learning outcomes and other expectations. The explanatory storyboard has to be offered to the educational technologists and the learning theories has to be determined by the designer. After the several revised, the themes and modules have been developed via several elearning material development tools. The ID process consists several work packages for the team. Correspondingly, eLearning development is of toilsome process that has been included in planning, storyboard, communication between instructional designers and subject experts, and time. Also, it has to be designed with an expert team, learning theories and other scientific methods.
\end{abstract}

Keywords: e-learning, material development, instructional design, nursing education

\section{INTRODUCTION}

The material design process must be suitable for the constructivist epistemology (Macleod \& Sinclair, 2015; Wang \& Hannafin, 2005) to get rich individual eLearning platforms (Keengwe, Onchwari, \& Agamba, 2014). The purpose of this inconvenient and multidisciplinary process is to support problem solving and critical thinking skills of students with appreciative learning methods and principles. From this point of view, the base of eLearning materials has to be transformed behaviorism to constructivism (Beetham \& Sharpe, 2013; Keengwe et al., 2014; Macleod \& Sinclair, 2015; Mullin, 2013).

As known, the main purpose of instructional design (ID) is to increase the learning outcomes of individuals via supportive materials (Taçgın \& Arslan, 2016). The ID decision must be depended on the cognitive abilities 


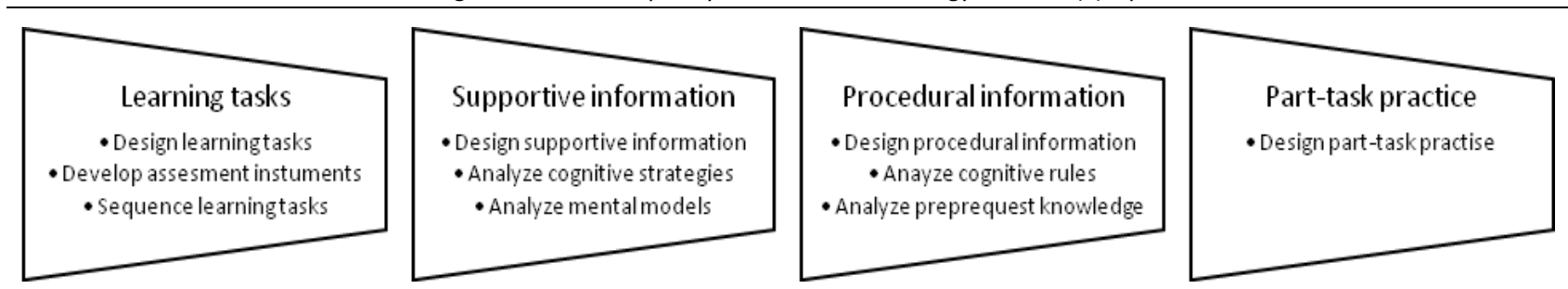

Figure 1. Four Blueprint components of ID 4C/10S (Van Merriënboer \& Kirschner, 2012)
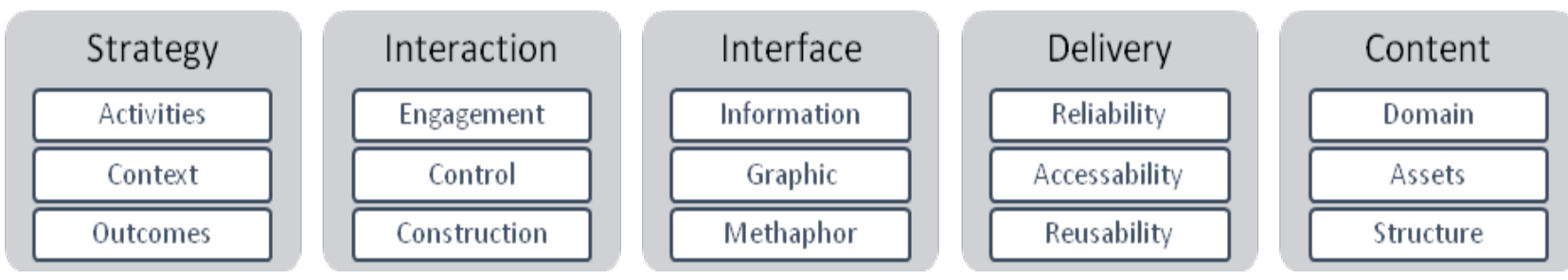

Figure 2. Design for learning model (Sims, 2012)

of learners to organize multimedia components (Beetham \& Sharpe, 2013; Keengwe et al., 2014). The 4 main components and stages of ID have been offered in Figure 1.

The chosen ID method selection and application depends on the educational need analysis that is the initial step of ID (Beetham \& Sharpe, 2013; Raspopovic, Cvetanovic, \& Jankulovic, 2016; Wegener \& Leimeister, 2012). The scopes, target abilities, presentation types and evaluation to measure learning have to be determined in this stage (Raspopovic et al., 2016). Then, the storyboard must be prepared as a representivescreen, media, interaction, other components. After the evaluation and updating the storyboard, eLearning material has been developed via several tools and pilot study must be applied to evaluate the exact capability of the material. Finally, the completed material has been uploaded to LMS in order to gather reports and measure the learning (Beetham \& Sharpe, 2013; Bork \& Rucks-Ahidiana, 2013; Lai \& Savage, 2013; Paquette, 2014; Raspopovic et al., 2016).

The ID methods are detected through learning outcomes despite the fact that every ID methods has cycling process and consists of 5 fundamental steps: analysis, design, implementation, development and evaluation (ADDIE) (Barab, 2006; Barab \& Squire, 2004; Lin \& Hsu, 2013; Raspopovic et al., 2016; Wang \& Hannafin, 2005). The successful ID process needs several actors: administrators, technicians, designers, teachers and learners (Barab \& Squire, 2004; Sims, 2012). In this process, the duties of actors have been categorized in Figure 2.

ID has been executed by the educational technologists or instructional designers that should plan the designing of new environment and principles to teach (Cengizhan, 2007). Additionally, the subject specialists have to organize the information (Keengwe et al., 2014) and evaluate the suitability of presenting components in accordance with the learning outcomes (Desai \& Mevada, 2015; Macleod \& Sinclair, 2015; Paquette, 2014; Raspopovic et al., 2016; Wegener \& Leimeister, 2012). The main responsibilities of educational technologists are to analyze education need and to determine the storyboard necessities. Moreover, they have an active role in the development phase to prepare the components -visual, audio, movie, fiction, integration (Raspopovic et al., 2016) in accordance with their sub-expertness. Because of this cooperation-based process, all of the communication channels have to be functional and, the evaluation phase has to be continued during each of the phases (Desai \& Mevada, 2015; Paquette, 2014; Raspopovic et al., 2016; Wegener \& Leimeister, 2012). This cycling and repetitive structure indicate that every material development process is the design - based research (Barab, 2006; Barab \& Squire, 2004; Raspopovic et al., 2016; Wang \& Hannafin, 2005). The main work packages and role of the actors are offered in Figure 3.

The determined design abilities indicate the necessary tools because material development software must be selected after synthesizing the necessities. According to the Raspopovic et al. (2016), the tools are categorized through presented material types as (1) comprehensive, (2) rapid eLearning, (3) test and evaluation, (4) screen capture, (5) mobile, (6) sophisticated simulation, (7) audio and video, and (8) virtual 


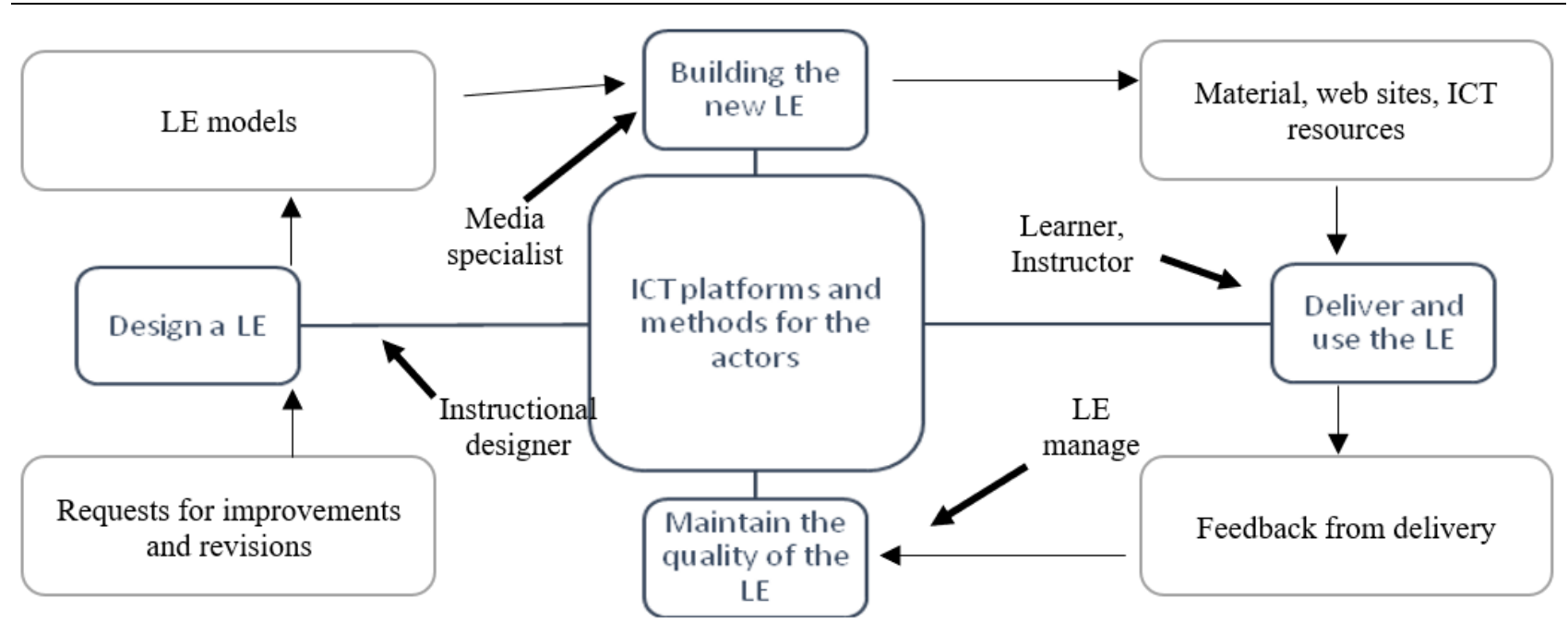

Figure 3. Basic life cycle of the learning environment (LE) (Paquette, 2014)

environment occurring programs. Also, each of tools includes several multimedia options to enhance the materials.

The constructivist approach aims to prompt meta-cognitional abilities of the individuals -analysis, synthesis, evaluation- in order to support comprehensive learning (Macleod \& Sinclair, 2015; Wang \& Hannafin, 2005). Thus, the comprehensive material development tools should be used to develop constructivist eLearning materials due to the multimedia editing and integrating capabilities. Also, educational technologists should use the tools effectively and have programming skills to edit the components. Some of the comprehensive material development tools are Sum Total Tool Book, Trivantis, Lectora, Articulate Storyline and ReadyGo also, the Articulate Storyline has been chosen one of the best software of 2015 (Mclntosh, 2014).

In the light of what is mentioned above, this study has been explained the ID process, actors, tools and usage purpose of the tools in accordance with the developed sample material modules that concerning birth lesson in nursing education. In this context, the purpose of this study is to demonstrate the most delicate part of eLearning material development process and tools in order to guide the actors.

\section{METHODOLOGY}

The aim of this design - based research is to demonstrate the relationship between theory-designimplementation through embodying the principles about teaching and learning (Cengizhan, 2007). The design-based research is intrinsically linked to, and its development nourished by, multiple design and research methodologies. Researchers assume the functions of both designers and researchers, drawing on procedures and methods from both fields, in the form of a hybrid methodology (Wang \& Hannafin, 2005). The used theories and methods in this research are (1) mastery learning theory of Bloom, (2) multimedia theory of Mayer, (3) ADDIE-based heuristic ID of Romizowski and (4) design - based research stages.

\section{THE PROJECT}

\section{The Project Team}

The researchers of design - based research have to be expert instructional designers also during the process, close cooperation with practitioners is necessary (Vanderhoven, Schellens, Vanderlinde, \& Valcke, 2015). In this concept, the roles, quantities and duties of the Project team have been offered in Table 1. 
Table 1. The project team

\begin{tabular}{|c|c|c|}
\hline Role & $f$ & Duties \\
\hline $\begin{array}{l}\text { Instructional designer \& } \\
\text { Material developer }\end{array}$ & 3 & $\begin{array}{l}\text { Giving information to the subject expert about the presentation of knowledge } \\
\text { Preparing the case diagram and determining sample screens } \\
\text { Teaching storyboard preparation to the subject expert } \\
\text { Designing and developing the sample screens } \\
\text { Integrating the knowledge to the sample screens in accordance with the ID principles } \\
\text { Editing and integrating the medias: visual, audio, video, etc. } \\
\text { Editing and integrating the micro learning videos } \\
\text { Designing and developing the drills and practices } \\
\text { Developing the animations and simulations } \\
\text { Adding the transactions between the screens } \\
\text { Creating and adding instruction } \\
\text { Uploading the material to the LMS } \\
\text { Testing the material periodically and revising it through the feedback }\end{array}$ \\
\hline Subject expert & 1 & $\begin{array}{l}\text { Analyzing the education need and determining the abilities of target } \\
\text { Analyzing the knowledge } \\
\text { Organizing the knowledge through the determined learning methods and techniques } \\
\text { Occurring the storyboard via presentation of the organized knowledge } \\
\text { Determining the measurement and evaluation methods } \\
\text { Providing the visual and audial components via studio records } \\
\text { Matching the media with subjects } \\
\text { Testing the material periodically and revising it through the feedback }\end{array}$ \\
\hline Subject matter consultant & 2 & Inspecting and evaluating each of the work packages of subject expert \\
\hline ID consultant & 1 & $\begin{array}{l}\text { Inspecting and evaluating the materials in accordance with the learning theories and } \\
\text { principles }\end{array}$ \\
\hline
\end{tabular}

\section{The Project Process}

The necessities of the design-based research process (Barab, 2006; Barab \& Squire, 2004; Wang \& Hannafin, 2005 ) have been ordered as (1) often conducted within a single setting over a long time, (2) iterative cycles of design, enactment, analysis, and redesign, (3) contextually dependent interventions, (4) document and connect outcomes with development process and the authentic setting, (5) collaboration between practitioners and researchers and (6) lead to the development of knowledge that can be used in practice and can inform practitioners and other designers.

\section{Step 1: Analysis of practical problems}

The results of the education need analysis of the subject expert and subject matter consultant indicate that the requirement of web-based learning environment due to the several deficiencies to teach the vaginal delivery -quantified restriction of manikin usage in the labs, impossibilities to practice and iteration caused by patient safety and ethical dichotomous, and difficulties in presenting the intangible concepts-. Additionally, it is highlighted that the principles of multimedia theory have to be used in order to support the comprehensive learning of the learners.

\section{Step 2: The development of solutions}

According to the analysis and evaluations of the subject expert, the determined material abilities:

- The vaginal delivery has 4 phases besides, $2^{\text {nd }}$ and $3^{\text {rd }}$ phases(modules) will be developed for this research

- Each of the modules has 5 main components: theoritical knowledge, skill practice, drill, self-evaluation, summary

- The high-fidelity is important to visuals that especially have to be explanatory for the critical skills 


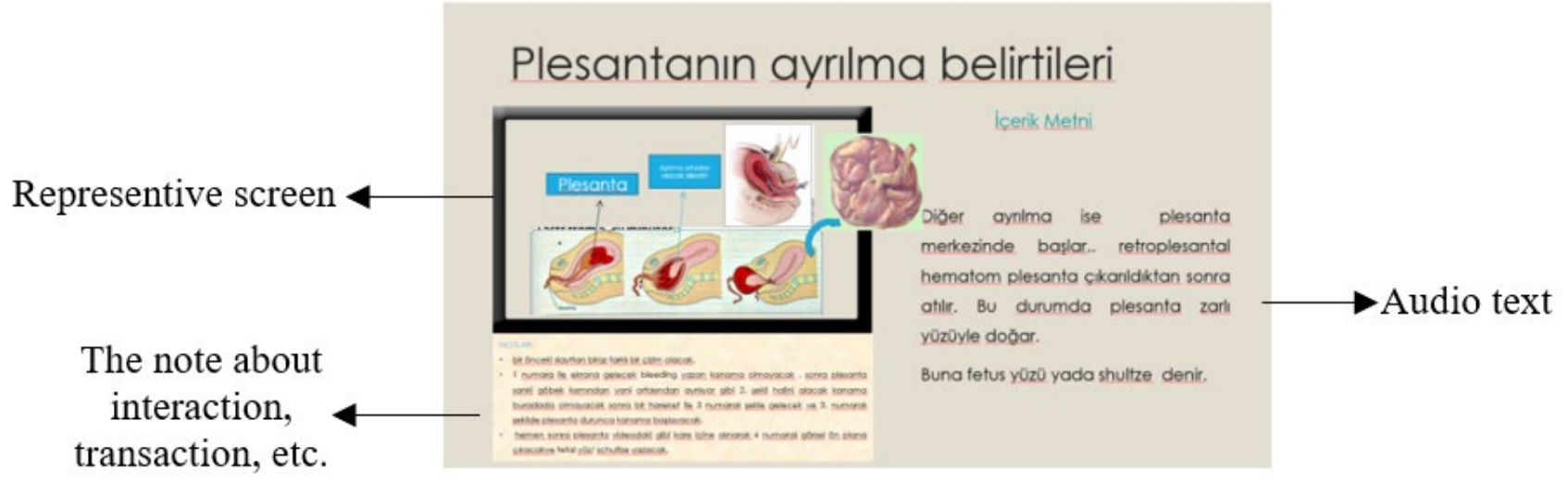

Figure 4. Storyboard screen sample

- The results of the drill and practice have to be reported

- The iteration opportunity must be offered to the learners

- After this detection and the meetings between the subject expert and instructional designer, the requirements to develop material have been demonstrate by the designer as below:

The raw visuals with studio recordings must be offered by the subject expert to reach high fidelity and correct guadience for the critical skills

- The learning outcome, goal and scope of each module must be determined

- The questions and answers of the drill and practice part must be offered by the subject expert

- The subject expert must prepare the storyboard within the organized knowledge and explanations. The storyboard must be clear and could be read by the educational technologists

- Each of the multimedia components - text, audio text, interaction, visual, animation, simulation, drill, video, etc. must be integrated into the storyboard.

The storyboard screen sample has been offered in Figure 4.

The storyboard has been (1) prepared by the subject expert, (2) evaluated by consultant and feedback, (3) revised by the expert and (4) offered to the instructional designers. Moreover, the spatial contiguity, temporal contiguity, modality, redundancy have been determined as the key points to offer individualized materials.

\section{Step 3: Evaluation research of the solutions in practice}

After the evaluation of storyboard, the case diagram has been created by the designer in order to describe the mapping of main screens, transactions between the modules and the storyline. Thus, the main screens and properties have been listed in Table 2. 
Table 2. Main screens and features

\begin{tabular}{|c|c|}
\hline Screen & Properties \\
\hline User entrance & Learners must start with the username \\
\hline Informing & The virtual instructor as a cartoon nurse character \\
\hline Learning outcomes & Must be offered at the beginning of module, text and audio \\
\hline Theoretical knowledge & $\begin{array}{l}\text { Analyzing the knowledge (content analyze), integrating into the designed themes via suitable } \\
\text { multimedia components }\end{array}$ \\
\hline $\begin{array}{l}\text { Stages of the skill } \\
\text { practice }\end{array}$ & $\begin{array}{l}\text { The nurse candidates must gain several skills in accordance with the procedure. These phases } \\
\text { have been designed as photo album that consists every stages of skills with explanatory } \\
\text { multimedias. The sequence of stages has been restricted for the first time of users. }\end{array}$ \\
\hline Abstract video & $\begin{array}{l}\text { It is placed between end of the theoretical and drill parts of the module. Optional to watch, } \\
\text { seek bar, passing through the drill. }\end{array}$ \\
\hline Drill and practice & $\begin{array}{l}\text { Multiple choice, true/false, matching, scenario-based story problems, ordering, drag and } \\
\text { drop, etc. } \\
\text { Visual feedbacks(color), informing, try again (depends on the choices), review, etc. }\end{array}$ \\
\hline Self-evaluation & End of the module, Likert type survey \\
\hline
\end{tabular}

Table 3. Main specialties of instructional design components

\begin{tabular}{|c|c|c|c|c|}
\hline Design & & Usability & & Learning outcomes \\
\hline Color & $\begin{array}{l}\text { Rectangle (tetradic) color scheme } \\
\text { to color variety } \\
\text { Complementary color to contrast } \\
\text { Primary: blue, Secondary: orange, } \\
\text { teritiary: green, red (to highlight) }\end{array}$ & Menu & $\begin{array}{l}\text { Menu, instruction, } \\
\text { exit, etc. must be } \\
\text { easily accessible }\end{array}$ & $\begin{array}{l}\text { Restriction must be in the content tree } \\
\text { for the first time }\end{array}$ \\
\hline Text & $\begin{array}{l}\text { Candara without Sans is } \\
\text { preferred to readability } \\
\text { Repetition -size of headings and } \\
\text { usage purpose- to code short } \\
\text { term memory }\end{array}$ & Instruction & $\begin{array}{l}\text { General instruction } \\
\text { considering usage, } \\
\text { virtual char to } \\
\text { immediate } \\
\text { feedback }\end{array}$ & Seek bar to user control \\
\hline Visuals & $\begin{array}{l}\text { Studio recording to high-fidelity } \\
\text { Other visuals have to be high } \\
\text { quality, harmony, proximity }\end{array}$ & $\begin{array}{l}\text { The virtual } \\
\text { character }\end{array}$ & $\begin{array}{l}\text { Instead of text, the } \\
\text { nurse char } \\
\text { guadience }\end{array}$ & $\begin{array}{l}\text { All multimedia components should } \\
\text { have harmony to transform to } \\
\text { perceived visuals and sounds to the } \\
\text { working memory. "to construct the } \\
\text { new knowledge" }\end{array}$ \\
\hline Metaphor & Basic, understandable, repetition & \multicolumn{2}{|c|}{$\begin{array}{l}\text { Instructions like color, bright, } \\
\text { shadow or sounds }\end{array}$} & $\begin{array}{l}\text { The constructive feedback has to be } \\
\text { offered to find the correct one } \\
\text { Drills could be reviewed to check }\end{array}$ \\
\hline
\end{tabular}

Table 4. Used material development softwares

\begin{tabular}{ll}
\hline Software & Propose \\
\hline Articulate Storyline 2.0 & $\begin{array}{l}\text { To integrate multimedia components, organizing the storyline, interaction, animation, } \\
\text { simulation, drill and practice, SCORM, etc. }\end{array}$ \\
$\begin{array}{ll}\text { Camtasia Studio 8.0 } & \text { Media editing: video, sound, visual, transaction, text } \\
\text { Adobe Photoshop } & \text { Media editing: picture, photo and drawing picture } \\
\text { Adobe Illustrator } & \text { Media editing: picture, photo and drawing picture } \\
\text { Adobe Flash } & \text { Animation }\end{array}$ \\
\hline
\end{tabular}

The ID components - (1) design, (2) usability and (3) learning outcomes- and usage purpose have been demonstrated in Table 3.

The used software to develop multimedia components and the materials have been offered in Table 4. 
Table 5. Multimedia components and editing software

\begin{tabular}{|c|c|c|c|}
\hline $2^{\text {nd }}$ module & $3^{\text {rd }}$ module & Software & Tools \\
\hline $\begin{array}{l}14 \text { studio } \\
\text { capture }\end{array}$ & $\begin{array}{l}21 \text { studio } \\
\text { capture }\end{array}$ & Adobe Photoshop & $\begin{array}{l}\text { Magic wandtool, Polygonallassotool, Clonestamptool, } \\
\text { Eraser, Paint buckettool, Smudgetool, Horizontaltypetool, } \\
\text { Blendingoptions, Hue / Saturation, Skew, perspective, wrap }\end{array}$ \\
\hline \multirow[t]{3}{*}{25 illustration } & $\begin{array}{l}5+10 \\
\text { illustration }\end{array}$ & Adobe Photoshop & $\begin{array}{l}\text { Magic wandtool, Polygonallassotool, Clonestamptool, } \\
\text { Eraser, Paint buckettool, Smudgetool, Horizontaltypetool, } \\
\text { Blendingoptions, Hue / Saturation, Skew, perspective, Wrap }\end{array}$ \\
\hline & & Adobe Illustrator & Shapebuildertool, Shapertool, Transform, Filters \\
\hline & & Photo Scape & To increase image quality \\
\hline 2 drawing & - & Adobe Photoshop & Brush, Hue / Saturation, Smudgetool, Paint buckettool \\
\hline 3 video & 2 video & Camtasia Studio 8.0 & $\begin{array}{l}\text { Library elements, Visual Properties, Hue andsaturation, } \\
\text { removebackground,Captions, Transitions }\end{array}$ \\
\hline $\begin{array}{l}48 \text { sound } \\
\text { record }\end{array}$ & $\begin{array}{l}42 \text { sound } \\
\text { record }\end{array}$ & Camtasia Studio 8.0 & Audio, silence, fade in , fade out, volumeup, clearvoice \\
\hline 4 animation & 2 animation & Articulate Storyline 2.0 & Animation menu items, Timeline, Marker, Trigger \\
\hline
\end{tabular}

Table 6. Main screen samples in accordance with themes

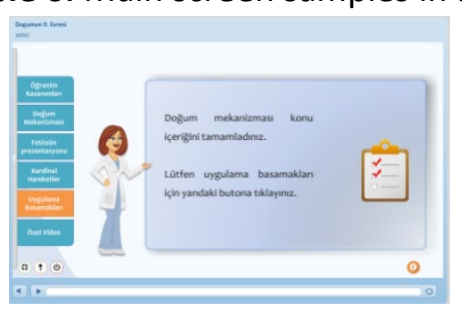

Quick access menu (a)

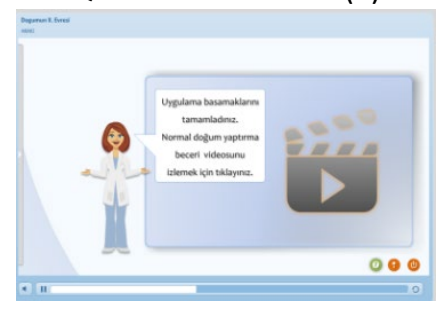

The video entrance (e)

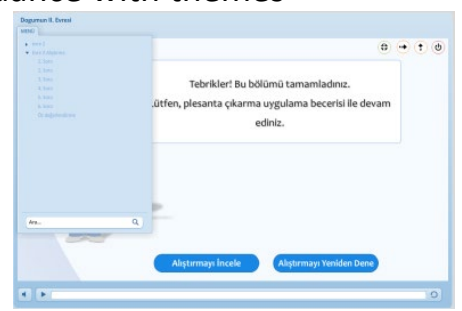

Standard menu (b)

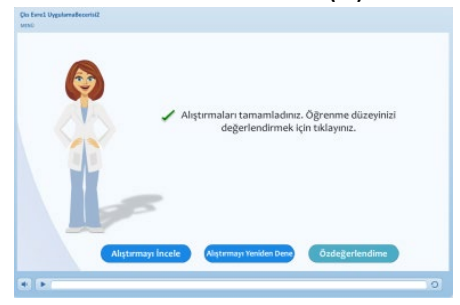

End of the drill (g)

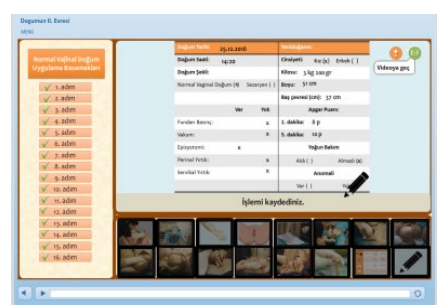

Last screen of the skill practice (d)

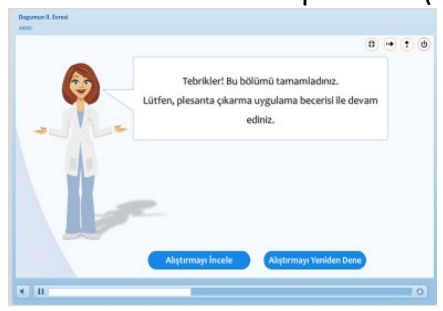

End of the module (h)

\section{Step 4: Reflection to produce design principles}

The quantities of multimedia components and editing software with used tools have been shown in Table 5 .

\section{Main Features}

Each of the modules has two transaction screens and they totally consist 22 screens. The screen design could be changed in accordance with containing multimedia. The layer structure of the Articulate Storyline has been used to present subcategories via triggers and the other layer properties. The fundamental screen samples of the modules have been offered in Table 6 .

As seen in Figure (a-b), two types of menu have been used. The quick access menu is the pull-right to use the screen effectively. Besides, the active heading has been presented with the complementary color. The menu includes the easy access buttons to the instruction, restart the module and exit via metaphors. The standard menu has been activated from the player properties of the Articulate Storyline and seek bar, search, restriction, subtitles and the other visual abilities has been set via that properties.

The photo album structure of the skill practice part has been seen in Figure (b). The students must proceed step by step by using the draft pictures below or the stage number at the left side. The presented stage 
Table 7. Explanations of the buttons and metaphors
(>) Next
(i) Information
(르 Instruction $\$$ Next module
(1) Video
C Restart
( Previous
(3) Drill part
(4) Exit
Restart module
Audio info
A Click

Table 8. Colors and visual components usage to categorize knowledge

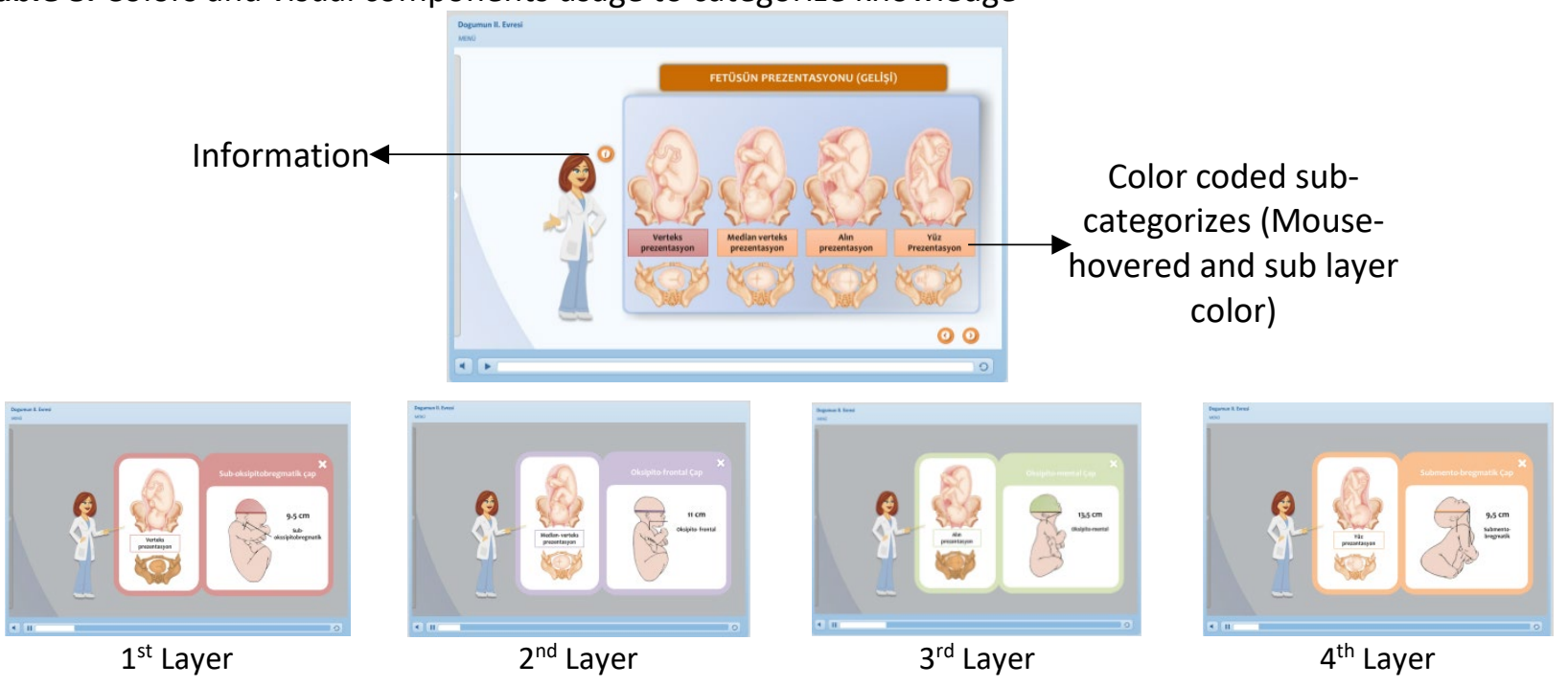

Table 9. Knowledge presentation screen samples

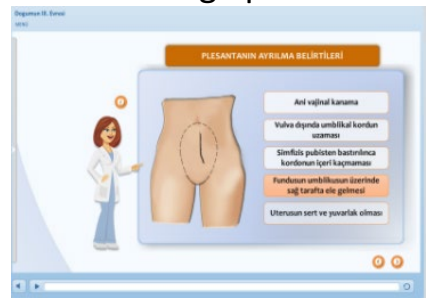

Tiered and repetitive (a)

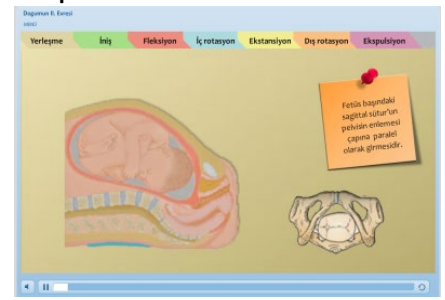

Categorized (b)

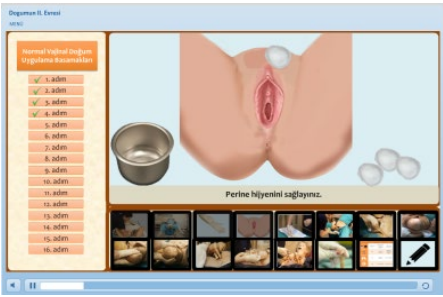

Animation (c)

picture has been shadowed for guadience and after completing this part, user can pass the abstract video or drill part of the module.

The abstract video has prepared via Camtasia Studio by using raw studio records. The length of the micro videos has been changed between 2 and 5 minutes and several multimedia components have been added to the enhancement. The watching video is optional and the seek bar is offered to user control. Also, the multimedia theory components have been applied to increase learning outcomes.

There repetition is the most important point for the metaphors in order to code short term memory and the consistency of the materials. The used metaphors have been demonstrated in Table 7. Moreover, the repetition has been applied to each of the multimedia components such as font, visuals, menu, etc.

As can be seen in Table 8, the colors of tetradic scheme and complimentary colors have been used to categorize the knowledge. The colors have been used to represent similar functions during the modules in order to transform coded knowledge at the short-term memory to through working memory.

As can be seen in Table 9, the visual presentation has been preferred instead of texts to make the intangible concepts more understandable. For instance, the visual and explanation have been offered together and tiered at the Figure a. The active order has been coded via complementary color and the learners can resee the phases after the presentation of the screen. 
Table 10. Drill and practice screen samples

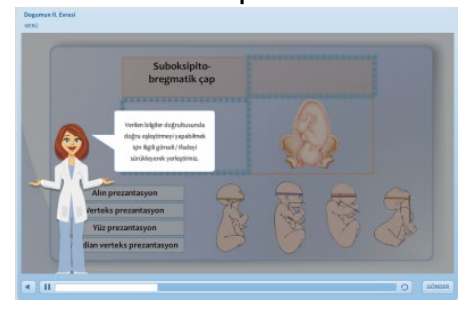

Info of question (a)

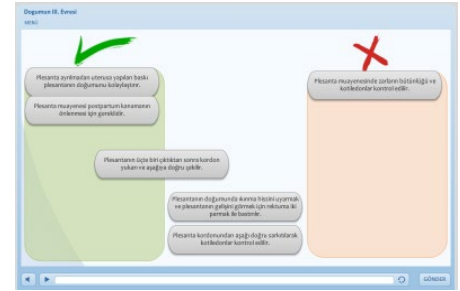

True-false matching question with drag and drop structure (d)

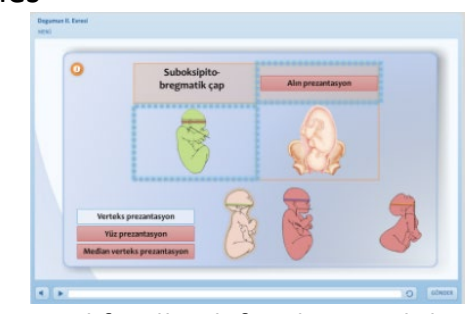

Visual feedback for drag and drop questions (b)

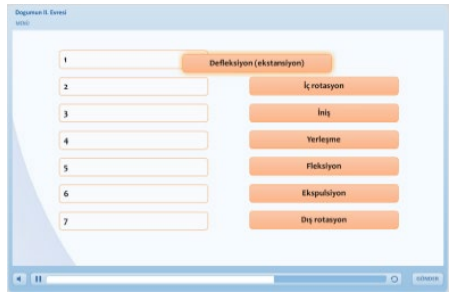

Ordering question (e)

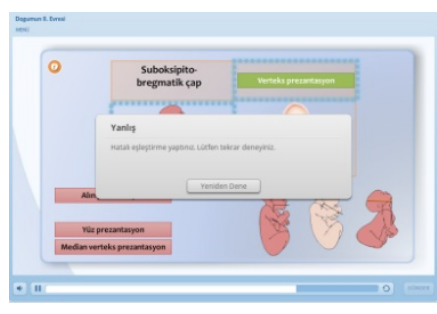

Standard feedback (c)

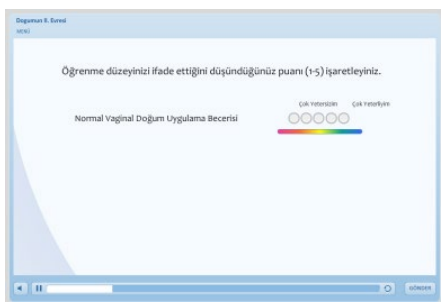

Self-evaluation form ( $f$ )

Some of the screen samples of the drill and practice parts have been shown in Table 10. As mentioned above, the modules consist of several question types - multiple choice, true/false, matching, scenario- based story problems, ordering, drag and drop, etc.-. From this point of view, the feedback has been designed in accordance within the type. For example, the drag and drop question of Figure $b$ and $c$ has 4 choices to put correct field. Correspondingly, learners have 3 chances to give correct answer to this question. Besides, after the wrong placed, the visual (b) and standart feedback (c) have been offered to the students. The visual feedback has been set via state function of the Articulate Storyline objects: drop correct, drop incorrect.

\section{RESULTS AND DISCUSSION}

The ID is the multidisciplinary process that needs several expert actors and cooperation between them to occur effective eLearning materials in accordance with the determined learning outcomes. This research has been executed to reveal the most delicate parts of the elearning material development process from the perspective of instructional designers.

The ID process has of evaluation and feedback-based recycling structure like the design-based research. Thus, it is possible to say that, the ID process should be managed scientifically via this methodology due to organizing ID phases and communication between the actors.

The education need analysis is the backbone of the ID process because the learning theory, techniques, evaluation methods, organized knowledge and other components must be chosen by the determined needs of learners. In this study, the multimedia theory principles of Mayer have been applied to occur individual eLearning environment. Thus, the properties of the design, usability and learning outcomes have been organized via related theories. Texts, visuals and other multimedia components have been designed carefully - the tetriadic and complementary colors, proximity, balance, contrast, texture, repetition, etc.- to augment the outcomes. Moreover, drills have been designed as a guidance with the constructivist feedback.

The standardization is the essential point to design the organized knowledge and storyboard has paramount significance in this point. For this reason, the storyboard must be clear and explanatory for the designers and developers in order to choose suitable software. The material development software has been classified by the functions and each of them needs a specialist to create influential elearning material. One of the comprehensive material development software as Articulate Storyline was used for this project. Additionally, Camtasia Studio and other visual editing software were used to create, edit or integrate the multimedia components. 
The two modules of this project have been developed in a year. Correspondingly, eLearning development and ID process are of toilsome process that has been included in project plan, storyboard, communication between instructional designers, developers, subject experts, and time.

\section{REFERENCES}

Barab, S. (2006). Design-Based Research: A Methodological Toolkit for the Learning Scientist. Cambridge, UK: Cambridge University Press. Retrieved from https://psycnet.apa.org/record/2006-07157-010

Barab, S., \& Squire, K. (2004). Design-based research: Putting a stake in the ground. The journal of the learning sciences, 13(1), 1-14. https://doi.org/10.1207/s15327809jls1301_1

Beetham, H., \& Sharpe, R. (2013). Rethinking pedagogy for a digital age: Designing for 21st century learning: London, UK: Routledge. Retrieved from https://www.taylorfrancis.com/books/e/9780203078952/ chapters/10.4324/9780203078952-14

Bork, R. J. H., \& Rucks-Ahidiana, Z. (2013). Role ambiguity in online courses: An analysis of student and instructor expectations. https://doi.org/10.7916/D8C24TGV

Cengizhan, S. (2007). Proje temelli ve bilgisayar destekli öğretim tasarimlarinin; bağimli, bağimsiz ve iş birlikli öğrenme stillerine sahip öğrencilerin akademik başarilarina ve öğrenme kaliciliğina etkisi [Projectbased and computer-aided teaching designs; the effect of students with dependent, independent and cooperative learning styles on academic success and learning retention]. Türk Eğitim Bilimleri Dergisi, 5(3), 377-403. Retrieved from https://dergipark.org.tr/en/download/article-file/256334

Desai, M. M., \& Mevada, M. S. (2015). Learning Online: A Review of Current Research on Issues of E-Learning, its Impacts and Challenges. The Global Journal of English Studies May, 1(1).

Keengwe, J., Onchwari, G., \& Agamba, J. (2014). Promoting effective e-learning practices through the constructivist pedagogy. Education and Information Technologies, 19(4), 887-898. https://doi.org/10.1007/s10639-013-9260-1

Lai, A., \& Savage, P. (2013). Learning Management Systems and Principles of Good Teaching: Instructor and Student Perspectives. Canadian Journal of Learning and Technology, 39(3). https://doi.org/10.21432/T24S39

Lin, C.-N., \& Hsu, H.-G. (2013). The Analogies Theory in the Design and Application of E-Learning Material. Paper presented at The International Conference on E-Technologies and Business on the Web (EBW2013).

Macleod, H., \& Sinclair, C. (2015). Digital Learning and the Changing Role of the Teacher. https://doi.org/10.1007/978-981-287-532-7_126-1

McIntosh, D. (2014). Vendors of learning management and e-learning products. Learning Management Vendors, 88-96. Retrieved from https://teachonline.ca/sites/default/files/pdfs/vendors_of_ elearning_products_march2018.pdf

Mullin, A. (2013). E-Learning Environment: Pedagogy Vs. Learning Theory in Design.

Paquette, G. (2014). Technology-based instructional design: Evolution and major trends. Handbook of Research on Educational Communications and Technology (pp. 661-671). Berlin, Germany: Springer. https://doi.org/10.1007/978-1-4614-3185-5_53

Raspopovic, M., Cvetanovic, S., \& Jankulovic, A. (2016). Challenges of Transitioning to e-learning System with Learning Objects Capabilities. The International Review of Research in Open and Distributed Learning, 17(1). https://doi.org/10.19173/irrodl.v17i1.2172 
Sims, R. (2012). Beyond instructional design: Making learning design a reality. Journal of Learning Design, 1(2), 1-9. https://doi.org/10.5204/jld.v1i2.11

Taçgın, Z., \& Arslan, A. (2016). The perceptions of CEIT postgraduate students regarding reality concepts: Augmented, virtual, mixed and mirror reality. Education and Information Technologies, 1-16. https://doi.org/10.1007/s10639-016-9484-y

Van Merriënboer, J. J., \& Kirschner, P. A. (2012). Ten steps to complex learning: A systematic approach to four-component instructional design. London, UK: Routledge. https://doi.org/10.4324/ 9780203096864

Vanderhoven, E., Schellens, T., Vanderlinde, R., \& Valcke, M. (2015). Developing educational materials about risks on social network sites: a design based research approach. Educational technology research and development, 1-22. Retrieved from https://core.ac.uk/download/pdf/55765585.pdf

Wang, F., \& Hannafin, M. J. (2005). Design-based research and technology-enhanced learning environments. Educational technology research and development, 53(4), 5-23. https://doi.org/10.1007/BF02504682

Wegener, R., \& Leimeister, J. M. (2012). Do Student-Instructor Co-Created eLearning Materials Lead to Better Learning Outcomes? Empirical Results from a German Large Scale Course Pilot Study. Paper presented at the System Science (HICSS), 2012 45th Hawaii International Conference on. https://doi.org/10.1109/HICSS.2012.227

Correspondence: Merve Kadioglu, Laboratory Corporation of America, USA.

E-mail: kadioglumerve@gmail.com 